\section{DIARY}

Oral-B Up To Date seminars

Dates and venues:

11 October 2012,

Radisson Blu Hotel, Manchester

8 November 2012,

Novotel St Pancras, London

22 November 2012, National

Motorcycle Museum, Birmingham

29 November 2012,

Celtic Manor, Newport

Telephone: 07585508550

Email:julia@ab-communications.com

ADI one-day Original

Dental Nurse Course

Date: 13 October 2012

Location: London

Telephone: 02084875555

www.adi.org.uk

Bruxism Awareness Week

Date: 22-28 October 2012

www.s4sdental.com

\section{BDTA Dental Showcase}

Date: 4-6 October 2012

Venue: ExCeL London

www.dentalshowcase.com

\section{BSDHT Oral Health}

Conference and Exhibition

Date: 9-10 November 2012

Venue: ACC, Liverpool

Telephone: 01452886365

www.bsdht.org.uk

ADI Advanced Dental

Nurses' Course

Date: 19 November 2012

Location: Edinburgh

Telephone: 02084875555

www.adi.org.uk

Expert Panel Consensus Meeting

on Monitoring, Diagnosis and

Treatment of Peri-implant Disease

Date: 19 November 2012

Venue: Savoy Place, London

Telephone: 02084875555

www.adi.org.uk/consensus 2012

ITI Education Week: Current

Treatment Principles and

Concepts in Implant Dentistry

Date: 26 November

- 1 December 2012

Location: London

www.iti.org/educationweek

\title{
LINDSAY SOCIETY CELEBRATES HALF CENTURY
}

2012 marks the fiftieth anniversary of the Lindsay Society for the History of Dentistry. To celebrate the work of the Society and the lady who inspired it, Lilian Lindsay CBE, this year the Society's annual conference has an exceptional programme of lectures and events planned and the British Dental Association (BDA) has a special exhibition.

Lilian Lindsay (1871-1960, pictured) was Britain's first qualified female dentist and a leading dental historian. The Lindsay Society was established in 1962 to promote interest in all aspects of the history of dentistry and has a journal, the Dental Historian.

The annual conference will take place in Cardiff from 5-7 October, with highlights including a lecture on 'How light revolutionised dentistry' by Nairn Wilson and vintage oral hygiene footage from the BDA Museum's collection.

The special BDA exhibition will mark the life of Lilian Lindsay and her contribution to dental history. It will show for the first time together the three portraits of Lilian commissioned by the BDA during her lifetime. These will be displayed alongside the notebooks detailing her meticulous research and the honours and awards she received.

The exhibition will run from 11 September 2012 until 15 January 2013 in the foyer of the BDA in London. For further information about the Society and its conference visit www.bda.org/linsdaysociety or email the secretary on brianwilliams14@btinternet.com.

\section{'TOOTH RECIPE' STEM CELL FOUND IN MICE}

Researchers in Helsinki, Finland, have found a marker for dental stem cells that could lead to the eventual goal of building a tooth.

Professor Irma Theslaff and her colleagues at the Institute of Biotechnology have showed that the transcription factor Sox 2 is specifically expressed in stem cells in the incisor of a mouse.

To build a tooth, a detailed 'recipe' to instruct cells to differentiate towards proper lineages and form dental cells is needed. However, the study of stem cells requires their isolation and a lack of a specific marker has so far hindered studies.

The mouse incisor grows continuously throughout the mouse's life and this growth is fuelled by stem cells located at the base of the tooth - offering an excellent model to study dental stem cells. The researchers developed a method to record the division, movement and specification of these cells. By tracing the descendants of genetically labelled cells, they also showed that Sox 2 positive stem cells give rise to enamel-forming ameloblasts as well as other cell lineages of the tooth.

'The mechanisms that control and regulate [human teeth] growth are similar to mouse teeth, says researcher Emma Juri. 'The discovery of Sox2 as a marker for dental stem cells is an important step toward developing a complete bioengineered tooth.'

\footnotetext{
Juuri E, Saito K, Ahtiainen L et al. Sox2+ stem cells contribute to all epithelial lineages of the tooth via Sfrp5+ progenitors. Dev Cell 2012; 23: 317-328.
}

\section{GDC UPDATE}

- Following a recent announcement by the General Medical Council (GMC) that doctors are to be banned from prescribing Botox remotely, the $\mathrm{GDC}$ is reminding its registrants that remote prescribing shall not be used in the provision of non-surgical cosmetic procedures such as the prescription or administration of Botox or injectable cosmetic medicinal products.

- When the annual deadline for dental care professionals (DCPs) to pay their annual retention fee (ARF) to the GDC passed on 31 July 2012, 58,346 DCPs had paid. Four thousand and twelve DCPs have now been removed from the GDC's register, 3,252 for nonpayment and 760 who requested to be taken off.

- In a year's time, 41,621 DCPs will come to the end of their first five-year cycle of continuing professional development (CPD). This means that they must complete 150 hours of CPD by 31 July 2013 , 50 hours of which must be verifiable, or risk losing their registration. The GDC is alerting CPD providers to the possibility of an increase in demand. 